Клімова А.М., к. пед. н., дои.

Київський національний торговельно-економічний університет, м. Київ, Україна Google Scholar https://scholar.google.com/citations?user=8tsomIgAAAAJ\&hl=en

\title{
БІЗНЕС-ПРОЕКТИ СТАРТАПІВ: НАЦІОНАЛЬНІ РЕАЛІЇ
}

Створення високоефективної і конкурентоспроможної туристичної індустрії $є$ перспективним напрямом розвитку національної економіки. У сучасних умовах глобалізації економіки туристична галузь потребує стратегічного розвитку і розробки універсальної схеми формування стратегії розвитку туризму.

Успішний розвиток туризму впливатиме на такі ключові сектори економіки, як транспорт, торгівля, будівництво, сільське господарство, виробництво товарів та послуг та сприятиме поповненню валютних запасів держави, підвищенню якості життя, забезпеченню зайнятості населення та зростання прибутків.

На сучасному етапі розвитку економіки найбільш актуальним стає питання виходу традиційного бізнесу на зовнішні ринки, розвиток бізнес-середовища для реалізації стартапів та інноваційних проектів. Зокрема, дану проблематику активно обговорюють та досліджують вітчизняні та зарубіжні вчені, підприємці, інвестори, стартапери, а саме: Пітер Тіль, Ф. Котлер, Боб Дорф, Д. Вонг, М. Портер, Є. Чазов, Л. Добрик, І. Чичкало-Кондрацька, Д. Кузьменко, I. Малишко, Р. Карц, Р. Баб'ячок, I. Кульчицький та ін.

На думку Чазова Є. В., «стартап - це хороша можливість для тих, у кого є мрія створити щось, що буде приносити користь людям i прибуток автору. Стартап - це процес реалізації абсолютно нової бізнес-ідеї за короткі терміни при мінімальній кількості фінансових ресурсів» [1, с. 123]. Ситник Н. I. запропонувала визначати стартап «як тимчасову організацію з високим інтелектуальним потенціалом, призначену для побудови стійкої масштабованої бізнес-моделі шляхом реалізації ідеї у вигляді інноваційного продукту» [2, с. 65].

Згідно даних Global Entrepreneurship Monitor, у 2016 p. 472 мільйони підприємців проводили активну роботу з розроблення і просування інноваційних ідей, за цей період було зареєстровано 
305 мільйонів стартапів [3]. В середньому ж кожного року в світі реєструється 100 мільйонів стартапів. Україна, маючи 173 стартапи, не ввійшла в десятку лідерів і має чималий відрив від провідних країн. Тобто засновникам вітчизняних стартапів потрібно вдосконалювати проекти, поліпшувати організацію менеджменту, працювати над залученням інвестицій.

Кожен стартап, варто розглядати як проект, який має певні етапи свого розвитку [4]:

1. Посівна стадія (seed stage). Це стадія появи ідеї. Деколи цю стадію розділяють на дві: pre-seed i seed. Це етап зародження ідеї, в основі якої лежить інноваційний продукт, послуга, технологія, здатна покращити чи полегшити життя, змінити існуючий товар, посилити ефект від дії товару чи послуги. На цьому етапі формується команда однодумців, які вірять у свою діяльність, розробляється приблизний план розвитку ідеї, розглядаються варіанти пошуку інвесторів.

2. Стадія запуску (startup stage). Завдання стартаперів на цій стадії - налагоджувати систему просування продукту і шукати джерела фінансування.

3. Стадія зростання (growth stage). Завданням стартаперів на цьому етапі стає остаточне формування продукту, послуги, технології, виправлення виявлених дефектів, тобто доведення його до ідеального стану.

4. Стадія розширення (expansion stage). Розширення - це стадія, коли компанія має завершений функціональний продукт, що приносить постійний прибуток.

5. Стадія «виходу» (exit stage). Найчастіше на цьому етапі компанія починає випуск акцій, які приносять дохід ії засновникам. В інших випадках компанію продають як готовий бізнес.

Отже, успішний стартап - це не просто реалізований проект - це «ідея-перевірка-навчання», згрупована команда, яка здатна навчатися на своїх помилках і не зупинятися на шляху втілення свого проекту.

Найголовніше правило стартапу - кожна невдача - це досвід, який допоможе створити надзвичайний продукт, який зможе зацікавити достатньо велику аудиторію споживачів та інвесторів, щоб бути комерційно вигідним.

Підводячи підсумок необхідно зауважити, що розвиток інноваційного бізнес-середовища для реалізації стартапів в Україні стимулює науково-технічний прогрес, який сприяє впровадженню новітніх світових досягнень. 


\section{Список бібліографічних посилань}

1. Чазов С. В. Стартап як нова форма ведення бізнесу. Наукові праці НУХТ. - 2013. - № 52. - С. 122-128.

2. Ситник Н. І. Концептуальні основи стартапів: їх сутність і класифікація. Бізнес Інформ. 2016. № 8. С. 64-68.

3. Global Entrepreneurship Monitor. доступу. - URL : http://www. gemconsortium.org.

4. Баб'ячок Р. І., Кульчицький I. I. Основні тенденції розвитку стартапів в Україні - проблеми, перешкоди і можливості. 2018. URL : https://www.civic-synergy.org.ua/wp content/uploads/2018/ 04/Osnovni-tendentsiyi-rozvytku-startapiv-v-Ukrayini-1-1.pdf. 